\title{
Fusion of batik printing and screen printing on Khadi saree using geometrical motifs
}

\author{
ANITA SINGH, ANITA SINGH AND PRIYAMBADA TRIPATHI
}

Received: 05.10.2016; Revised: 10.11.2016; Accepted: 22.11.2016

See end of the paper for authors' affiliations ANITA SINGH

Department of Home Science, Shri Agrasen Kanya P.G. College, VARANASI (U.P.) INDIA
ABSTRACT : India has always been known as the land that port yard, cultural and traditional vibrancy through its conventional arts and crafts. Every region in India has its own style which is very ethnic and simple and yet colourful and vibrant enough to speaks volumes about the rich heritage. Colour design has been used to enhance the intrinsic beauty of textile from ancient time. It is believed that ornamentation by dyeing and printing developed earlier that the use of clothing itself. Design is the knowledgeable selection and application of the basic art element i.e. line, shape, colour and texture to produce a unified expressive visual statement. Screen printing is a versatile process for design applications on textiles. The present study was conducted to fusion of batik printing and screen printing on Khadi saree using geometrical motifs.10 geometrical motifs were identified for application in sarees and create with self. Created motifs were got evaluated from 100 respondents and 4 top ranked motifs were selected. 4 designs were finally selected for application of saree which were placed with all possible variations. The final printed sarees were again shown in front of same respondents in the way of colour combination, placement of motifs, cost, purchasing preference and overall appearance. 5 point scale was used for grading. For saree no. 1 overall appearance (8.2) was most preferred followed by colour combination (3.8) and placement of design (1.6).for saree no. 2 colour combination (8) was most preferred followed by overall appearance (3.2).

KEY WORDS: Batik printing, Screen printing, Saree, Khadi

- HOW TO CITE THIS PAPER : Singh, Anita, Singh, Anita and Tripathi, Priyambada (2016). Fusion of batik printing and screen printing on Khadi saree using geometrical motifs. Asian J. Home Sci., 11 (2) : 429-434, DOI: 10.15740/HAS/AJHS/11.2/429-434. 